\title{
Greenhouse Soil Biosolarization with Tomato Plant Debris as a Unique Fertilizer for Tomato Crops
}

\author{
Pablo García-Raya ${ }^{1, *(\mathbb{D})}$, César Ruiz-Olmos ${ }^{1}$, José Ignacio Marín-Guirao ${ }^{1}$, \\ Carlos Asensio-Grima ${ }^{1}$, Julio César Tello-Marquina ${ }^{1}$ and Miguel de Cara-García ${ }^{2}$ (B) \\ 1 CIAIMBITAL, Campus de Excelencia Internacional Agroalimentario, Universidad de Almería, \\ Carretera Sacramento s/n, 04120 Almería, Spain; ceroan22@hotmail.com (C.R.-O.); \\ jignaciomarin@gmail.com (J.I.M.-G.); casensio@ual.es (C.A.-G.); jtello@ual.es (J.C.T.-M.) \\ 2 IFAPA-La Mojonera, Camino San Nicolás n.1, 04745 La Mojonera, Spain; \\ franciscom.cara@juntadeandalucia.es \\ * Correspondence: pgr335@ual.es; Tel.: +34-950-015-527
}

Received: 10 November 2018; Accepted: 15 January 2019; Published: 19 January 2019

\begin{abstract}
Intensive greenhouse horticulture can cause various environmental problems. Among these, the management, storage, and processing of crop residues can provoke aquifer contamination, pest proliferation, bad odors, or the abuse of phytosanitary treatments. Biosolarization adds value to any fresh plant residue and is an efficient technique for the control of soil-borne diseases. This study aims to examine an alternative means of managing greenhouse crop residues through biosolarization and to investigate the influence of organic matter on yield and quality of tomato (Solanum lycopersicum, L.) fruit. With this purpose, the following nutritional systems were evaluated: inorganic fertilization with and without brassica pellets (Fert, Fert +, and Fert ++), fresh tomato plant debris with and without brassica pellets (Rest, Rest + , and Rest ++ ), and no fertilizer application (Control). The addition of organic matter was equal across all the treatments except for the control with regard to yield and quality of the tomato fruit. In light of these results, the application of tomato plant debris to the soil through biosolarization is postulated as an alternative for the management of crop residues, solving an environmental problem and having a favorable impact on the production and quality of tomatoes as a commercial crop.
\end{abstract}

Keywords: tomato; biofumigation; organic; inorganic fertilizer; sustainability; environment

\section{Introduction}

Protected agriculture in the Mediterranean basin has maintained a sustained growth over the last decades due to the increase of human population and the demand for vegetables. According to Castilla [1], in 2010 the total area dedicated to the cultivation of greenhouse vegetables in the Mediterranean basin reached up to 200,000 ha. The province of Almería (southeast Spain), with a protected area of 30,456 ha and commercial production of fruit and vegetables valued at $2537 \mathrm{M} €$ (tomato production corresponded to $540 \mathrm{M} €$ ), was considered to be the main core of protected horticultural production in Europe in 2016 [2].

However, the location of production has led to environmental problems, such as the pollution and eutrophication of aquifers, mainly due to the excessive use of pesticides, synthetic nitrogenous fertilizers, or excessive irrigation when chemical disinfection is applied [3-7]. Another problem is the management of crop residues due to the seasonality in the waste production [8]. In particular, in 2014 Almería produced approximately 1,900,000 tons of non-dehydrated residues from horticultural crops $[8,9]$. Furthermore, organic matter resources, such as green manure, mulching, animal manure, 
and crop waste, are frequently added to the soil through biofumigation and biosolarization to prepare the soil for the next crop [10,11].

Biosolarization [12], as a combination of biofumigation [13] and solarization [14], is a technique which can involve the application of any type of organic amendment with disinfection properties to the soil. The advantages of using the biosolarization technique include increased temperature due to the combined action of plastic sheet and the decomposition of organic matter $[15,16]$, improved water use and soil structure [17], reduced erosion and salinity [18], increased organic matter content $[19,20]$, organic matter solubilization [21], $\mathrm{CO}_{2}$ capture during the development of the biofumigant crop [22], and the acceleration of in situ decomposition of plant waste from crops which reduces the transition time between crops [23].

The increased introduction of ecological systems of production (50.9 Mha worldwide) [24], as well as the need for various organic amendments for plant nutrition, highlight greenhouse waste as viable for application through biosolarization.

The aim of this study is to evaluate the addition of organic matter (i.e., crop residues) as fertilizers and test if this organic amendment is sufficient to support profitable tomato crops grown under an intensive production system.

\section{Materials and Methods}

\subsection{Location, Climate, and Soil}

The trial was conducted in two consecutive years (2015-2016, 2016-2017) at the University of Almería-ANECOOP Experimental Research Center in Almería $\left(36.518^{\circ} \mathrm{N}, 2.178^{\circ} \mathrm{W}\right)$. The local climate is Mediterranean arid with mild winters and hot, dry summers (average annual rainfall below $250 \mathrm{~L} \cdot \mathrm{m}^{-2}$ ). The experimental greenhouse was an Almería-type "raspa y amagado" greenhouse [25], the most common in the area. The greenhouse had an area of $1700 \mathrm{~m}^{2}$, with a northwest to southeast orientation and crops rows aligned northeast to southwest. The soil was composed of a mixture of sand and soil [26]. The history of previous crops as well as preliminary analyses showed absence of tomato soilborne pathogens in soil. During the cropping periods, no soil treatments were applied. Soil nutrition analysis was performed previously to plant transplants. Soil samples were taken at seven points throughout the greenhouse at a depth of $0-30 \mathrm{~cm}$; the soil mix was analyzed by an accredited laboratory. At the start of the experiment, the soil consisted of $14.33 \%$ clay, $72.24 \%$ sand, and $13.43 \%$ silt. Soil $\mathrm{pH}$ was 7.56 , organic matter content was $0.78 \%$, total nitrogen $(\mathrm{N})$ was $700 \mathrm{mg} \cdot \mathrm{kg}^{-1}$, available phosphorus (P) was $61.43 \mathrm{mg} \cdot \mathrm{kg}^{-1}$, and exchangeable potassium (K) was $365 \mathrm{mg} \cdot \mathrm{kg}^{-1}$.

The greenhouse had a drip irrigation system with $3-\mathrm{L} \cdot \mathrm{h}^{-1}$ emitters. In the same greenhouse during previous years (2013-2014 and 2014-2015), two tomato crops were grown with the incorporation of organic matter. In the first year, the crop was transplanted on 2 September 2015 and remained for 173 days. In the second year (2016), the crop was planted on 6 September and remained for 170 days. The plants were tomato cv. Pitenza F1 (Enza Zaden, Enkhuizen, the Netherlands) at a density of two plants per $\mathrm{m}^{2}$. Plants consisted of a single stem; axillary shoots were eliminated and the plant was trained along a polypropylene rope. Irrigation was performed based on readings of a Model $\mathrm{R}$ tensiometer (Irrometer, Riverside, CA, USA) which was placed at a depth of $30 \mathrm{~cm}$; irrigation was performed at pressures between -15 and $-20 \mathrm{KPa}$. Control of pests and diseases was carried out in a conventional manner according to environmental practices and legislation. Pollination was forced with the use of bumblebees at a density of four hives per ha.

Air temperature in the greenhouse was measured using a Hobo U23-001 Pro v2 temperature data logger (Onset Computer Corp., Bourne, MA, USA). During the growing period, the minimum, average, and maximum temperatures in the greenhouse were $12.60 \pm 2.14{ }^{\circ} \mathrm{C}, 18.13 \pm 1.77^{\circ} \mathrm{C}$, and $27.69 \pm 3.06{ }^{\circ} \mathrm{C}$ in the first season, and $11.78 \pm 4.16^{\circ} \mathrm{C}, 18.52 \pm 4.63^{\circ} \mathrm{C}$, and $30.46 \pm 6.05^{\circ} \mathrm{C}$ in the second season. 


\subsection{Experimental Design, Fertilization, and Soil Disinfection}

The experimental design comprised seven treatments with four replications randomly distributed in two large zones (i.e., organic and inorganic). In this way, three treatments were in the inorganic zone and four in the organic zone of the greenhouse. Each elementary plot had an area of $40 \mathrm{~m}^{2}$, each containing 80 plants. The two zones of the greenhouse each had an independent irrigation system. In the inorganic zone of the greenhouse, the following treatments applied to the soil with inorganic fertilization were used (the nutritive solution is reported in Table 1): Nutritive solution (Fert); Nutritive solution and $0.5 \mathrm{~kg} \cdot \mathrm{m}^{-2}$ of Biofence ${ }^{\circledR}$ (Fert + ); Nutritive solution and $1 \mathrm{~kg} \cdot \mathrm{m}^{-2}$ of Biofence ${ }^{\circledR}($ Fert ++$)$. In the organic area of the greenhouse, the treatments amended with different organic materials and/or exclusive irrigation with water without fertilizer were as follows: $3.5 \mathrm{~kg} \cdot \mathrm{m}^{-2}$ of fresh tomato plant debris (Rest); $3.5 \mathrm{~kg} \cdot \mathrm{m}^{-2}$ of fresh tomato plant debris and $0.5 \mathrm{~kg} \cdot \mathrm{m}^{-2}$ of Biofence ${ }^{\circledR}$ $($ Rest +$) ; 3.5 \mathrm{~kg} \cdot \mathrm{m}^{-2}$ of fresh tomato plant debris and $1 \mathrm{~kg} \cdot \mathrm{m}^{-2}$ of Biofence ${ }^{\circledR}$ (Rest ++ ). The trial had a "zero" treatment (Control), which involved irrigation with water only, without the use of fertilizer or organic matter. The nutritional characteristics of the commercial product, Biofence ${ }^{\circledR}$, are presented in Table 1. For the preparation of the organic amendments, fresh tomato plant debris from the previous production cycle was chopped to a particle size of less than $3 \mathrm{~cm}$ using tractor-powered hammer grinders and incorporated into the soil with a rototiller at the previously reported doses. The tomato debris consisted of the remaining plants at the end of the previous crop. This material included neither fruits nor roots. The existing compositional data of tomato debris is sparse and shows considerable variability among various nutrient levels [27-30]. The chemical characteristics of tomato plant debris used were: nitrogen $(\mathrm{N}) 4.12 \%$, phosphorus $(\mathrm{P}) 0.40 \%$, potassium $(\mathrm{K}) 2.83 \%$, calcium $(\mathrm{Ca}) 3.43 \%$, and magnesium $(\mathrm{Mg}) 0.86 \%$. The commercial product, Biofence ${ }^{\circledR}$, was applied along the crop row prior to the solarization of the specified treatments. All the treatments were subjected to biosolarization or solarization in the two growing periods for 60 days before transplanting the crop by covering the soil with a transparent polyethylene plastic sheet $(0.05 \mathrm{~mm}$ thickness). The temperature was measured at 15-cm depth during the period of (bio)solarization at two points in the greenhouse using a Hobo U23-001 Pro v2 temperature probe (Onset Computer Corp., Bourne, MA, USA). Soil wetting was carried out after placing the plastic sheet using the same irrigation system, adding water up to field capacity $\left(30 \mathrm{~L} \cdot \mathrm{m}^{-2}\right)$. Irrigation water was analyzed during the two years of research to confirm the absence of fertilizer.

Table 1. Nutrition systems used.

\begin{tabular}{cc}
\hline \multirow{3}{*}{ Nutritive Solution } & $\mathrm{NO}_{3}{ }^{-}: 11 \mathrm{mmol} \cdot \mathrm{L}^{-1}, \mathrm{H}_{2} \mathrm{PO}_{4}^{-}: 1.5 \mathrm{mmol} \cdot \mathrm{L}^{-1}, \mathrm{SO}_{4}{ }^{2-}: 2 \mathrm{mmol} \cdot \mathrm{L}^{-1}$, \\
& $\mathrm{K}^{+}: 7.5 \mathrm{mmol} \cdot \mathrm{L}^{-1}, \mathrm{Ca}^{2+}: 5 \mathrm{mmol} \cdot \mathrm{L}^{-1}, \mathrm{Mg}^{2+}: 2 \mathrm{mmol} \cdot \mathrm{L}^{-1}$. \\
E.C. increased from 0.5 to $3.0 \mathrm{dS} \cdot \mathrm{m}^{-1}$ during crop development. \\
\hline \multirow{2}{*}{ Biofence $^{\circledR}$} & Dehydrated and defatted pellets of Brassica carinata, $6 \% \mathrm{~N}, 3.1 \% \mathrm{P}$, \\
& $2.2 \% \mathrm{~K}, 1.8 \% \mathrm{~S}, 0.5 \% \mathrm{Mg}$. Triumph Italia. \\
\hline
\end{tabular}

\subsection{Parameters Analyzed}

\subsubsection{Tomato Yield}

During the growth of the crop, several parameters were measured and/or calculated for each harvest, such as yield, accumulated yield (calculated), and weight per fruit, using a Metter Toledo electronic scale. The weight per fruit was obtained from the average weight of 25 fruits with representative characteristics of the sample set. Fruits which had suitable commercial characteristics and were of the desired ripeness for consumption were harvested.

\subsubsection{Fruit Quality}

The quality of the tomato fruit was evaluated three times in each crop cycle, using 10 marketable fruits per experimental plot (280 fruits in each of the three samplings, 840 in total). The analyzed 
parameters were as follows: equatorial diameter with a digital caliber (Mitutoyo); firmness of the pulp with a penetrometer (Agrosta Penefel DFT14) with an end of $0.5 \mathrm{~cm}^{2}$. Three measurements were taken in each fruit with gaps of $120^{\circ}$. Prior to measurement, the fruit cuticle was removed at each site. Fruit $\mathrm{pH}$ was determined with a $\mathrm{pH}$-meter Crison $\mathrm{pH}-25+$ with penetrating electrode. Fruit soluble solids pulp content was measured with a digital refractometer (Atago pal-1) and fruit color was measured with a colorimeter (Konica Minolta CR400). Three measurements were taken in each fruit, in three equidistant places of the equatorial zone, with gaps of $120^{\circ}$. The tomato color values were recorded as $\mathrm{A}^{*} / \mathrm{B}^{*}$.

\subsection{Statistical Analyses}

After finding that both trials could be considered statistically equal for the accumulated yield parameter, the results were analyzed as one individual experiment for a more consistent analysis. On the other hand, given that for the other tomato yield parameters (i.e., mean yield and weight per fruit) and for the quality fruit parameters the effect of year was significant and both trials could not be considered statistically equal, the results were analyzed separately. The analysis carried out for the comparisons between treatments consisted of simple analysis of variance (ANOVA) and means separated by Tukey's honest significant difference test $(p<0.05)$. As this was a parametric analysis, the conditions of normality and homoscedasticity were checked previously (Shapiro-Wilk and Levene tests, respectively). The statistical package used was STATGRAPHIC CENTURION XVI v16.2.04 (Manugistic Incorporate, Rockville, MD, USA) for Windows.

\section{Results}

\subsection{Tomato Yield}

\subsubsection{Accumulated Tomato Yield}

The accumulated yield during both crops (Figure 1) was consistent and did not show differences depending on the nutrition system used. Treatments with crop debris (with and without Biofence ${ }^{\circledR}$ ) produced the same yield as plants that were fertigated (with and without Biofence ${ }^{\circledR}$ ). All the treatments produced higher yields than the control.

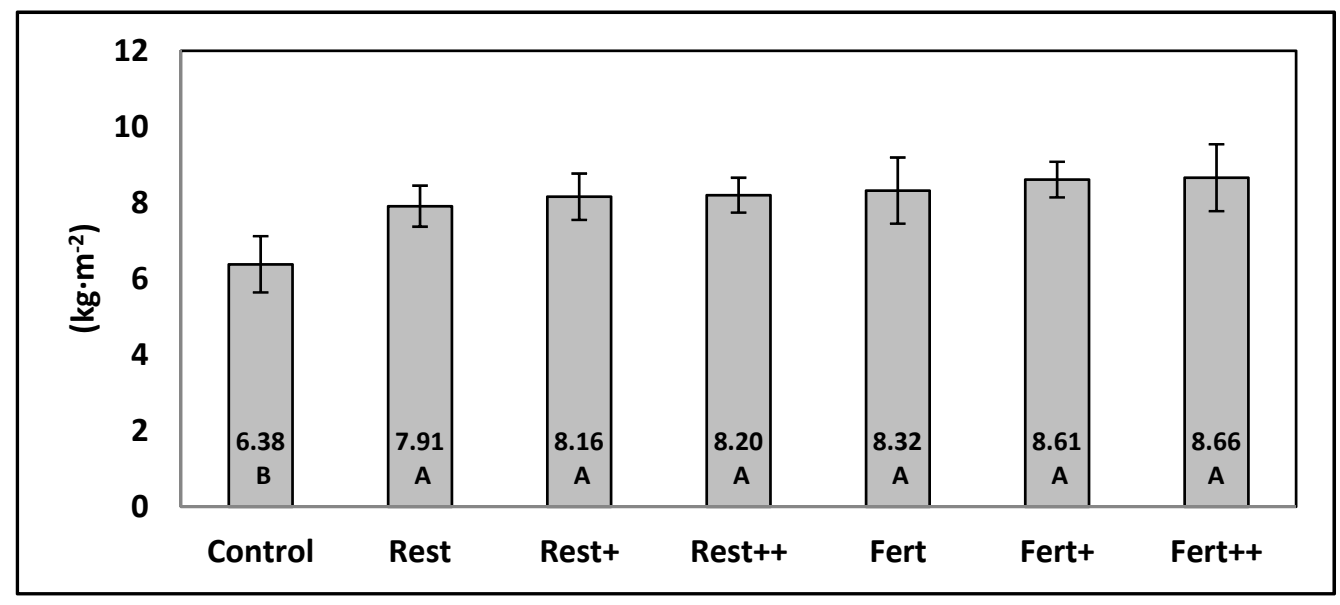

Figure 1. Effect of soil bio-disinfection treatments with tomato plant debris (with and without brassica pellets) as a unique fertilizer, and inorganic fertilization treatments (with and without brassica pellets) in the accumulated yield of tomato fruits. The results correspond to the average of two seasons. Different letters indicate significant differences ( $p \leq 0.05$, Tukey's honest significant difference (HSD) test). 


\subsubsection{Yield per Harvest}

The average yield for each harvest (Table 2) was similar to the first crop cycle ( $p$-value $>0.005$ ); the Control treatment produced substantially less throughout the cropping period, but the yield was not significantly different from the others treatments. With the second crop, differences between treatments were observed, and as occurred in the accumulated production, the treatments with crop debris (with and without Biofence ${ }^{\circledR}$ ) produced the same yield as the fertigated treatments (with and without Biofence ${ }^{\circledR}$ ). With the Control treatment, yield was lower with the second crop and was significantly different compared to the other treatments.

Table 2. Effect of soil biosolarization treatments with tomato plant debris (with and without brassica pellets) as a unique fertilizer, and of inorganic fertilization treatments (with and without brassica pellets) on tomato yield and fruit quality variables in two growing seasons (autumn-winter).

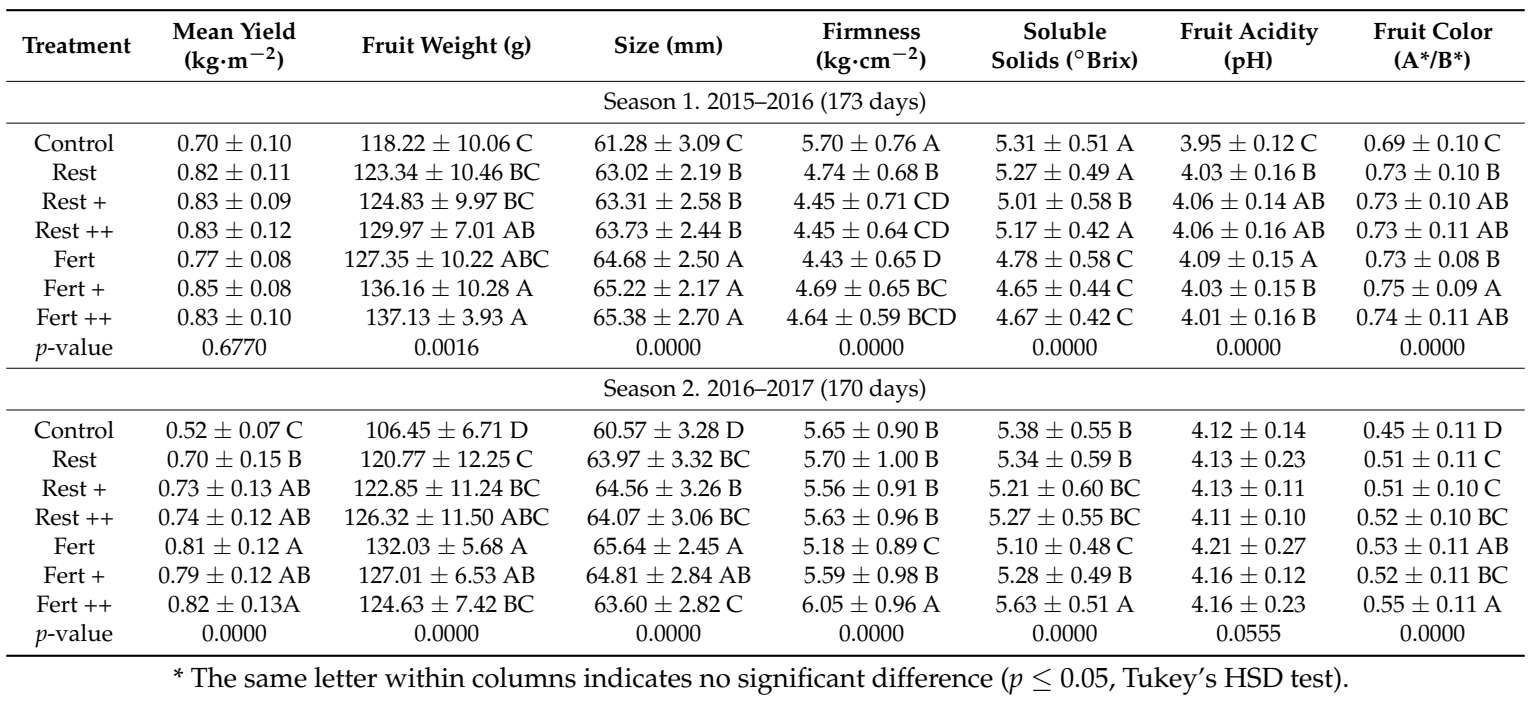

\subsubsection{Weight per Fruit}

The weight per fruit was affected during the first growing cycle by the type of fertilization (Table 2). The treatments with inorganic fertilization produced fruits of greater weight but was not significantly different from the other nutritional treatments, except for the Rest and Control treatments. Fruits from the Rest + and Rest ++ treatment groups were of similar weight to fruits with other treatments. In the second crop, treatments with crop residues produced fruits of similar weight to those of treatments with fertigation. During the two years, control fruits had lower weights compared to any other treatment in both years of cultivation.

\subsection{Fruit Quality}

\subsubsection{Size}

The size of the tomato fruits was smaller in the treatments with crop residues in the first crop (Table 2), although in the second crop treatments with crop residues produced fruits of similar size to those from the fertigated treatments. In both years, the Control treatment was the one that produced the smallest fruit. In all cases, the average size of the fruits was in the range of $M$ values of $57-67 \mathrm{~mm}$, which is a commercial standard.

\subsubsection{Firmness}

The firmness of the fruits (Table 2) was affected by the treatments in both production cycles. In the first crop, the control fruits were the hardest compared to the other treatments. In the second crop, 
there was no difference between most of the treatments, with Fert ++ , Rest, and Control being the treatments with the highest firmness values. The Fert treatment produced the softest fruits.

\subsubsection{Soluble Solids}

The fruits from soil treated with crop residues and from the control were the sweetest in the first tomato crop. In the second crop, these differences were not apparent, with Fert ++ and Control treatments resulting in the sweetest fruits; the other treatments resulted in fruits with a similar soluble solids content (Table 2).

\subsubsection{Acidity of the Fruit}

The fruit acidity (Table 2) was affected by the nutrition of the plants in the first crop. The control fruits had a lower $\mathrm{pH}$, and the rest of the treatments resulted in fruits with very similar values, although there was a significant difference between them. In the second crop, no significant differences were observed between soil treatments ( $p$-value $>0.005$ ).

\subsubsection{Color}

The parameter $\mathrm{A}^{*} / \mathrm{B}^{*}$ (Table 2) showed differences between treatments in the first crop, although they were minimal and imperceptible to the human eye. The Control treatment resulted in the lowest values. In the second crop, the parameter $\mathrm{A}^{*} / \mathrm{B}^{*}$ showed differences between treatments, which were minimal and negligible, similar to the previous year because the harvesting took place at the same point of maturity. Again, the Control treatment presented the lowest values during the second crop.

\section{Discussion}

Several authors have studied in depth the benefits for production of using techniques such as biofumigation or biosolarization in several crops [31-42].

On the other hand, there are few studies investigating plant nutrition based exclusively on the addition of organic matter applied under biosolarization in a greenhouse. Most authors supplement soil with synthetic fertilizer during the development of the crop. For this reason, it is difficult to compare past results with those from this study. The current results indicate that in both years the treatments that received organic matter did not differ from those that were fertigated, for isolated harvestings as well as for accumulated yield. Iapichino et al. [36] reported that tomatoes grown after carrying out the biosolarization technique with brassica residue $\left(2 \mathrm{~kg} \cdot \mathrm{m}^{-2}\right)$ and inorganic fertilization showed higher commercial production than those grown with only solarized treatments. Ros et al. [43] evaluated the biosolarization technique with various organic materials (sheep and chicken manure) and reported a greater production of pepper fruit with the use of manures; the authors did not specify whether they used an inorganic fertilizer in the culture.

Mauromicale et al. [44] reported an increase in tomato yield (up to $70 \%$ depending on the treatment) when organic matter composed of cow dung, poultry manure, and leather was incorporated into the soil prior to solarization. Again, Mauromicale et al. [16] found that the addition of compost based on cattle or horse manure prior to solarization (i.e., biosolarization) had a positive effect on the physical and chemical properties of tomato fruits in the southeast of Italy. Nuñez-Zofío et al. [45], in a trial of bio-disinfection of soils in the Basque Country, found improved production in pepper crops after the addition of various organic materials, with an increase in production of $59 \%$ with semi-composted sheep manure and poultry manure. The previous authors did not specify if they performed inorganic fertilization during the development of the crop. Marín-Guirao et al. [11] concluded that biosolarization with residues of brassicas and pellets of chicken manure supplemented with inorganic fertilization benefited tomato crops, improving the yield and organoleptic tomato fruit characteristics. The findings reported by these authors demonstrate the positive effects of biosolarization when it is supplemented with organic matter and fertigation, obtaining yields and fruits with a fruit quality comparable to a conventional system. However, the application of inorganic fertilization plus organic matter must 
be carried out with consideration of the global contribution of macronutrients to the system, so as to optimize resources and reduce costs. In this sense, the current research is postulated as an evolution of the techniques used by the previous authors, reducing the contribution of inorganic fertilizer to zero in the treatments with crop residues and obtaining a comparable yield to that obtained with a conventional production system.

It is necessary to analyze the control yield; this treatment was solarized in both growing years of this experiment. Solarization could be involved in the solubilization of remaining nutrients of soil, thus reaching commercial production without the addition of fertilizers. Stapleton et al. [21] found a similar effect when solarizing with transparent plastic; the authors reported an increase in the content of $\mathrm{NO}_{3}{ }^{-}$and $\mathrm{NH}_{4}{ }^{+}$available for post-solarization cultivation. Lombardo et al., [39] quoting Katan [14], speculated that solarization by itself can potentiate the growth and development of the plant by coining the term "increased growth response" and suggested that this is due to a rapid release of nutrients.

The use of Biofence ${ }^{\circledR}$ as an organic material did not provoke an improvement either in yield or in the organoleptic properties of tomato fruit in crops over both years. Supplementation with the pellets resulted in an improvement in yield, though this change was not significant. These findings are partly consistent with those of López-Aranda et al. [46], Pane et al. [47], and Marín-Guirao et al. [11], who did not report any benefit with Biofence ${ }^{\circledR}$ application. Pane et al. [47] suggested that the application of brassica carinata flour, with or without solarization, could have a protective effect on some microbial groups that benefit soil activity and the establishment of the crop. However, Guerrero et al. [48] tested Biofence ${ }^{\circledR}$ for the control of nematodes of the genus Meloidogyne did not find any benefits from its use, as it was ineffective in controlling nematodes and had no positive effect on pepper production compared to the use of fresh manures. With regard to this study, the use of the commercial product, Biofence $^{\circledR}$, represented a financial investment with no corresponding increase in yield to justify its use.

The quality parameters of the tomato fruit were affected by the type of fertilization. It should be noted that the fruits from plants treated with fertigation, in the first year, had higher size and weight than fruits of the others treatments, but this was not maintained in the second year. It is noteworthy that Marín-Guirao et al. [11] obtained values for acidity, ${ }^{\circ}$ Brix, and color similar to those obtained in this study. However, Mauromicale et al. [16] reported that parameters such as firmness, color, and soluble solids content $\left({ }^{\circ}\right.$ Brix) were increased proportionally to the increase in organic matter in the treatments used, contrasting with the results of this study. In our study, the Control treatment showed an increase similar to that reported by Mauromicale et al. [16], which may be due to the scarcity of nutrients with no organic amendment.

From a commercial point of view, the two systems of vegetable nutrition produced fruit suitable for consumption: caliber M (57-67 mm), very high firmness $\left(>2 \mathrm{~kg} \cdot \mathrm{cm}^{-2}\right)$, and color between the E and $\mathrm{F}$ categories. It should be noted that the values of ${ }^{\circ} \mathrm{Brix}$ and $\mathrm{pH}$ were closer to a "cherry" tomato type than to a long-life tomato $[49,50]$.

\section{Conclusions}

The incorporation of plant debris at the end of the crop cycle using biosolarization has been shown to be an efficient practice for the management of this residue, solving the problem of handling crop residues by offering a technique that respects the environment, benefits the circular economy, and provides a reference for horticultural production systems, even for the transition to organic farming. The addition of organic amendments provides the necessary nutrients for the correct development of a greenhouse tomato culture (5-6 months), achieving the same yield as a conventional inorganic fertilization system and, furthermore, maintaining the main organoleptic properties of the fruit while also being economically beneficial for growers. Future research should be focused on determining the impact on the water footprint due to improved soil structure as a result of organic matter, an aspect of vital importance for the protected agriculture of the Mediterranean basin. 
Author Contributions: Conceptualization, J.C.T.-M. and C.R.-O.; methodology, J.I.M.-G. and C.R.-O.; investigation, C.R.-O. and P.G.-R.; resources, C.A.-G.; writing—original draft preparation, P.G.-R.; writing-review and editing, J.I.M.-G. and M.d.C.-G.; supervision, J.I.M.-G and M.d.C.-G.; project administration, J.C.T.-M.; funding acquisition, J.C.T.-M. and P.G.-R.

Funding: This research was funded by the University of Almería PPIT and the AGR200 research group, Almería, Spain.

Acknowledgments: We thank the UAL-ANECOOP Foundation Experimental Research Center for their collaboration and assistance during the development of this study.

Conflicts of Interest: The authors declare no conflict of interest.

\section{References}

1. Castilla, N. Greenhouse Technology and Management, 2nd ed.; CABI: Wallingford, UK, 2013; pp. 1-335, ISBN 9781780641034. Available online: https://www.cabi.org/bookshop/book/9781780641034 (accessed on 9 November 2018).

2. Cabrera, A.; Uclés, D.; Aguera, T.; de la Cruz, E. Análisis de la campaña hortofrutícola de Almería: Campaña 2016/2017. Editorial Fundación Cajamar 2017, 1, 1-59. Available online: http:/ / www.publicacionescajamar.es/series-tematicas/informes-coyuntura-analisis-de-campana/ analisis-de-la-campana-hortofruticola-de-Almería-campana-2016-2017/ (accessed on 9 November 2018).

3. Lamichhane, J.R. Pesticide use and risk reduction in European farming systems with IPM: An introduction to the special issue. Crop Prot. 2017, 97, 1-6. Available online: https://www.sciencedirect.com/science/ article/pii/S0261219417300261 (accessed on 9 November 2018). [CrossRef]

4. Ramos, C.; Agut, A.; Lidón, A.L. Nitrate leaching in important crops of the Valencian Community region (Spain). Environ. Pollut. 2002, 118, 215-223. Available online: https://www.ncbi.nlm.nih.gov/pubmed/ 11939284 (accessed on 9 November 2018). [CrossRef]

5. Vázquez, N.; Pardo, A.; Suso, M.L.; Quemada, M. Drainage and nitrate leaching under processing tomato growth with drip irrigation and plastic mulching. Agric. Ecosyst. Environ. 2006, 112, 313-323. Available online: https:/ / www.sciencedirect.com/science/article/pii/S0167880905003816 (accessed on 9 November 2018). [CrossRef]

6. Thompson, R.B.; Martínez-Gaitan, C.; Gallardo, M.; Giménez, C.; Fernández, M.D. Identification of irrigation and $\mathrm{N}$ management practices that contribute to nitrate leaching loss from an intensive vegetable production system by use of a comprehensive survey. Agric. Water Manag. 2007, 89, 261-274. Available online: https://www.sciencedirect.com/science/article/pii/S0378377407000376?via\%3Dihub (accessed on 9 November 2018). [CrossRef]

7. Yasuor, H.; Ben-Gal, A.; Yermiyahu, U.; Beit-Yannai, E.; Cohen, S. Nitrogen management of greenhouse pepper production: Agronomic, nutritional, and environmental implications. HortScience 2013, 48, 1241-1249. Available online: http:/ / hortsci.ashspublications.org/content/48/10/1241.full (accessed on 9 November 2018).

8. Junta de Andalucía. Estrategia de gestión de restos vegetales en la horticultura de Andalucía. Consejería de Agricultura y Pesca y Desarrollo Rural; Consejería de Medio Ambiente y Ordenación del Territorio 2016, 1, 1-45. Available online: https://www.juntadeandalucia.es/export/drupaljda/Lineas_actuacion_materia_gestion_ restos_vegetales_horticultura_Andalucia.pdf (accessed on 9 November 2018).

9. López-Hernández, J.C.; Pérez-Martínez, C.; Acien-Fernández, F.G. Residuos vegetales procedentes de los invernaderos de Almería. Publicaciones Cajamar 2016, 17, 1-9. Available online: https:/ / www.cajamar.es/pdf/bd/agroalimentario/innovacion/formacion/actividades-de-transferencia/ 017-restos-vegetales-1466406472.pdf (accessed on 9 November 2018).

10. Kumar, V.; Abdul-Baki, A.; Anderson, J.D.; Mattoo, A.K. Cover crop residues enhance growth, improve yield, and delay leaf senescence in greenhouse-grown tomatoes. HortScience 2005, 40, 1307-1311. Available online: http:/ / hortsci.ashspublications.org/content/40/5/1307.abstract (accessed on 9 November 2018).

11. Marín-Guirao, J.I.; Tello, J.C.; Díaz, M.; Boix, A.; Ruiz, C.A.; Camacho, F. Effect of greenhouse soil bio-disinfection on soil nitrate content and tomato fruit yield and quality. Soil Res. 2016, 54, 200-206. Available online: http:/ / www.publish.csiro.au/SR/SR15106 (accessed on 9 November 2018). [CrossRef] 
12. Bello Pérez, A.; González-Pérez, J.A.; Tello, J.C. La biofumigación como alternativa a la desinfección de suelos. Hortic. Int. 1997, 43, 41-43. Available online: http://digital.csic.es/bitstream/10261/84815/1/La\% 20biofumigaci\%C3\%B3n\%20como\%20alternativa.pdf (accessed on 9 November 2018).

13. Kirkegaard, J.A.; Gardner, P.A.; Desmarchelier, J.M.; Angus, J.F. Biofumigation-using Brassica species to control pests and diseases in horticulture and agriculture. In Proceedings of the 9th Australian Research Assembly on Brassica, Wagga Wagga, Australia, 5-7 October 1993; Volume 1, pp. 77-82. Available online: https:/ / publications.csiro.au/rpr/pub?list=BRO\&pid=procite:1ab24273-efdb-43d2-a034071ccfa128c4 (accessed on 9 November 2018).

14. Katan, J. Solar heating (solarization) of soil for control of soilborne pests. Annu. Rev. Phytopathol. 1981, 19, 211-236. Available online: https:/ /www.annualreviews.org/doi/abs/10.1146/annurev.py.19.090181.001235 (accessed on 9 November 2018). [CrossRef]

15. Scopa, A.; Candido, V.; Dumontet, S.; Miccolis, V. Greenhouse solarization: Effects on soil microbiological parameters and agronomic aspects. Sci. Hortic. 2008, 116, 98-103. Available online: https://www. sciencedirect.com/science/article/pii/S0304423807004037 (accessed on 9 November 2018). [CrossRef]

16. Mauromicale, G.; Longo, A.M.G.; Lo Monaco, A. The effect of organic supplementation of solarized soil on the quality of tomato fruit. Sci. Hortic. 2011, 129, 189-196. Available online: https:/ /www.sciencedirect. com/science/article/pii/S0304423811001324 (accessed on 9 November 2018). [CrossRef]

17. Chan, K.Y.; Heenan, D.P. The influence of crop rotation on soil structure and soil physical properties under conventional tillage. Soil Tillage Res. 1996, 37, 113-125. Available online: https:/ /www.sciencedirect.com/ science/article/pii/0167198796010082 (accessed on 9 November 2018). [CrossRef]

18. McGuire, A.M. Mustard Green Manures Replace Fumigant and Improve Infiltration in Potato Cropping System. Crop Manag. 2003, 2, 1-6. Available online: https://dl.sciencesocieties.org/publications/cm/ abstracts/2/1/2003-0822-01-RS (accessed on 9 November 2018). [CrossRef]

19. Bailey, K.L.; Lazarovits, G. Suppressing soil-borne diseases with residue management and organic amendments. Soil Till. Res. 2003, 72, 169-180. Available online: https:/ / www.sciencedirect.com/science/ article/pii/S0167198703000862 (accessed on 9 November 2018). [CrossRef]

20. Thorup-Kristensen, K.; Magid, J.; Jensen, L.S. Catch crops and green manures as biological tools in nitrogen management in temperate zones. Adv. Agron. 2003, 79, 227-302. Available online: http:/ / www.orgprints. org/107/ (accessed on 9 November 2018). [CrossRef]

21. Stapleton, J.J.; Quick, J.; Devay, J.E. Soil solarization-Effects on soil properties, crop fertilization and plant-growth. Soil Biol. Biochem. 1985, 17, 369-373. Available online: https://www.sciencedirect.com/ science/article/abs / pii/0038071785900756 (accessed on 9 November 2018). [CrossRef]

22. Lazzeri, L.; Malaguti, L.; Cinti, S.; Ugolini, L.; De Nicola, G.R.; Bagatta, M.; Casadei, N.; D’Avino, L.; Matteo, R.; Patalano, G. The brassicaceae biofumigation system for plant cultivation and defence. An italian twenty-year experience of study and application. Acta Hortic. 2013, 1005, 375-382. Available online: https:/ / www.actahort.org/books/1005/1005_44.htm (accessed on 9 November 2018). [CrossRef]

23. Reddy, P.P. Biofumigation and Solarization for Management of Soil-Borne Plant Pathogens, 1st ed.; Scientific Publishers: Jodhpur, India, 2011; pp. 1-431, ISBN 9788172336974. Available online: http:/ / www.scientificpub.com/book-details / Biofumigation-and-Solarization-for-Management-ofSoil-Borne-Plant-Pathogens-151.html (accessed on 9 November 2018).

24. Willer, H.; Lernoud, J. The World of Organic Agriculture. Statistics and Emerging Trends; Research Institute of Organic Agriculture FiBL and IFOAM Organics International: Frick, Switzerland, 2016; Available online: https://shop.fibl.org/CHde/mwdownloads/download/link/id/785/?ref=1 (accessed on 9 November 2018).

25. Valera, D.L.; Belmonte, L.J.; Molina-Aiz, F.D.; López, A.; Camacho, F. The greenhouses of Almería, Spain: Technological analysis and profitability. Acta Hortic. 2017, 1170, 219-226. Available online: https:/ /www. actahort.org/books/1170/1170_25.htm (accessed on 9 November 2018). [CrossRef]

26. Bretones, C. El enarenado. In Técnicas de Producción en Cultivos Protegidos, 1st ed.; Instituto Cajamar: Madrid, España, 2003; Volume 1, pp. 110-118, ISBN 84-95531-15-1. Available online: http:/ / www.publicacionescajamar.es/pdf/series-tematicas/agricultura/tecnicas-de-produccion-encultivos-2.pdf (accessed on 9 November 2018). 
27. Contreras París, J.; Baeza Cano, R.J.; Segura Pérez, M. Cuantificación de los nutrientes aportados al suelo por la incorporación de los restos de los cultivos hortícolas en invernaderos. Agricultura y ganadería ecológica 2015, 11, 18-19. Available online: https:/ / www.agroecologia.net/recursos/publicaciones/actas/cd-actasxicongresoseae/actas / comunicaciones /67-cuantificacion-nutrientes-contreras-resumen.pdf (accessed on 9 November 2018).

28. Moreno Casco, J.; Moral Herrero, R. Compostaje, 1st ed.; Mundi-Prensa: Madrid, España, 2008; pp. 1-572, ISBN 9788484763468. Available online: https:/ /www.mundiprensa.com/catalogo/9788484763468/compostaje (accessed on 9 November 2018).

29. Casas Castro, A.; Casas Barba, E. Análisis de suelo-agua-planta y su aplicación en la nutrición de los cultivos hortícolas en la zona del sureste peninsular. Publicaciones Cajamar 1999, 1, 1-249. Available online: http:/ /www.publicacionescajamar.es/series-tematicas/agricultura/analisis-de-sueloagua-planta-y-su-aplicacion-en-la-nutricion-de-cultivos-horticolas-en-la-zona-peninsular/ (accessed on 9 November 2018).

30. Fernández, P.; Pascual, J.; Lacasa, A. Potencial de lixiviación de nitratos de la técnica de biosolarización en suelos de invernaderos de pimiento. Sociedad Española de Ciencias de Hortícolas 2014, 66, 107-115. Available online: http: / / www.sech.info/ ACTAS / Acta\%20n\%C2\%BA\%2066.\%20V\%20Jornadas\%20del\%20grupo\% 20de\%20fertilizaci\%C3\%B3n/Sesi \%C3\%B3n\%201.\%20Cultivos\%20Hort\%C3\%ADcolas/Potencial\%20de \% 20lixiviaci\%C3\%B3n\%20de\%20nitratos\%20de\%20la\%20t\%C3\%A9cnica\%20de\%20biosolarizaci\%C3\% B3n\%20en\%20suelos\%20de\%20invernaderos\%20de\%20pimiento.pdf (accessed on 9 November 2018).

31. Chen, Y.; Katan, J.; Gamliel, A.; Aviad, T.; Schnitzer, M. Involvement of soluble organic matter in increased plant growth in solarized soils. Biol. Fertil. Soils 2000, 32, 28-34. Available online: https://link.springer.com/ article/10.1007/s003740000209 (accessed on 9 November 2018). [CrossRef]

32. Guerrero, M.M.; Martínez, M.A.; Ros, C.; Martínez, M.C.; Bello, A.; Lacasa, A. Biosolarización y biofumigación para la producción de pimiento ecológico en invernadero. Sociedad Española de Agricultura Ecológica 2006, 103, 1-8. Available online: https://www.agroecologia.net/recursos/publicaciones/ publicaciones-online/2006/CD\%20Congreso\%20Zaragoza/Ponencias/103\%20Guerrero\%20Com\%20Biosolarizaci\%C3\%B3n.pdf (accessed on 9 November 2018).

33. Martínez, M.A.; Guerrero, M.M.; Martínez, M.C.; Ros, C.; Lacasa, A.; Tello, J.C. Efecto de la biosolarización reiterada sobre la microbiota fúngica en cultivos de pimiento. Sociedad Española de Agricultura Ecológica 2006, 212, 1-10. Available online: https:/ / www.agroecologia.net/recursos/publicaciones/publicaciones-online/ 2006/CD\%20Congreso\%20Zaragoza/Ponencias/212\%20Martinez\%20Com-\%20Efecto.pdf (accessed on 9 November 2018).

34. Díez-Rojo, M.; López-Pérez, J.; Urbano-Terrón, P.; Bello, A. Biodesinfección de Suelos y Manejo Agronómico; Ministerio de Medio Ambiente y Medio Rural y Marino: Madrid, España, 2010; 407p, Available online: https://www.miteco.gob.es/va/calidad-y-evaluacion-ambiental/publicaciones/libro\%20de \% 20biodesinfecci\%C3\%B3n_tcm39-185072.pdf (accessed on 9 November 2018).

35. Fernández-Bayo, J.D.; Achmon, Y.; Harrold, D.R.; McCurry, D.G.; Hernandez, K.; Dahlquist-Willard, R.M.; Stapleton, J.J.; VanderGheynst, J.S.; Simmons, C.W. Assessment of Two Solid Anaerobic Digestate Soil Amendments for Effects on Soil Quality and Biosolarization Efficacy. J. Agric. Food Chem. 2017, 65, 3434-3442. Available online: https:/ / www.ncbi.nlm.nih.gov/pubmed/28409935 (accessed on 9 November 2018). [CrossRef]

36. Iapichino, G.; Puleo, L.; Vetrano, F.; Sciortino, A. Effects of Solarization and Biofumigation on Tomato Greenhouse Production in the Southern Coast of Sicily. Acta Hortic. 2008, 801, 1557-1562. Available online: https:/ / www.actahort.org/books/801/801_192.htm (accessed on 9 November 2018). [CrossRef]

37. Porras, M.; Barrau, C.; Romero, E.; Zurera, C.; Romero, F. Effect of Biofumigation with Brassica carinata and Soil Solarization on Phytophthora spp. and Strawberry Yield. Acta Hortic. 2008, 842, 969-972. Available online: https: / / www.actahort.org/books/842/842_215.htm (accessed on 9 November 2018). [CrossRef]

38. Garibaldi, A.; Gilardi, G.; Clematis, F.; Gullino, M.L.; Lazzeri, L.; Malaguti, L. Effect of Green Brassica Manure and Brassica Defatted Seed Meals in Combination with Grafting and Soil Solarization against Verticillium Wilt of Eggplant and Fusarium Wilt of Lettuce and Basil. Acta Hortic. 2010, 883, 295-302. Available online: https:/ / www.actahort.org/books/883/883_36.htm (accessed on 9 November 2018). [CrossRef] 
39. Lombardo, S.; Longo, A.M.G.; Lo Monaco, A.; Mauromicale, G. The effect of soil solarization and fumigation on pests and yields in greenhouse tomatoes. Crop Prot. 2012, 37, 59-64. Available online: https://www. sciencedirect.com/science/article/pii/S0261219412000373 (accessed on 9 November 2018). [CrossRef]

40. Hansen, Z.R.; Keinath, A.P. Increased pepper yields following incorporation of biofumigation cover crops and the effects on soilborne pathogen populations and pepper diseases. Appl. Soil Ecol. 2013, 63, 67-77. Available online: https:/ / www.sciencedirect.com/science/article/pii/S0929139312002302 (accessed on 9 November 2018). [CrossRef]

41. Suja, G.; Byju, G.; Jyothi, A.N.; Veena, S.S.; Sreekumar, J. Yield, quality and soil health under organic vs conventional farming in taro. Sci. Hortic. 2017, 218, 334-343. Available online: https:/ / www.sciencedirect. com/science/article/pii/S0304423817300912 (accessed on 9 November 2018). [CrossRef]

42. Achmon, Y.; Sade, N.; Wilhelmi, M.; Fernandez-Bayo, J.D.; Harrold, D.R.; Stapleton, J.J.; VanderGheynst, J.S. Effects of Short-Term Biosolarization Using Mature Compost and Industrial Tomato Waste Amendments on the Generation and Persistence of Biocidal Soil Conditions and Subsequent Tomato Growth. J. Agric. Food Chem. 2018, 66, 5451-5461. Available online: https://www.ncbi.nlm.nih.gov/pubmed/29763301 (accessed on 9 November 2018). [CrossRef] [PubMed]

43. Ros, M.; Garcia, C.; Hernandez, M.T.; Lacasa, A.; Fernandez, P.; Pascual, J.A. Effects of biosolarization as methyl bromide alternative for Meloidogyne incognita control on quality of soil under pepper. Biol. Fertil. Soils 2008, 45, 37. Available online: https:/ /link.springer.com/article/10.1007/s00374-008-0307-1 (accessed on 9 November 2018). [CrossRef]

44. Mauromicale, G.; Monaco, A.L.; Longo, A.M.G. Improved efficiency of soil solarization for growth and yield of greenhouse tomatoes. Agron. Sustain. Dev. 2010, 30, 753-761. Available online: https://link.springer.com/ article/10.1051/agro/2010015 (accessed on 9 November 2018). [CrossRef]

45. Nuñez-Zofío, M.; Larregla del Palacio, S.; Garbisu, C. Repeated biodisinfection controls the incidence of Phytophthora root and crown rot of pepper while improving soil quality. Spanish J. Agric. Res. 2012, 10, 794-805. Available online: http://revistas.inia.es/index.php/sjar/article/view/2342 (accessed on 9 November 2018). [CrossRef]

46. López-Aranda, J.M.; Miranda, L.; Domínguez, P.; Soria, C.; Pérez-Jiménez, R.M.; Zea, T.; Talavera, M.; Velasco, L.; Romero, F.; De Los Santos, B. Soil biosolarization for strawberry cultivation. Acta Hortic. 2012, 926, 407-413. Available online: https://www.actahort.org/books/926/926_57.htm (accessed on 9 November 2018). [CrossRef]

47. Pane, C.; Villecco, D.; Pentangelo, A.; Lahoz, E.; Zaccardelli, M. Integration of soil solarization with Brassica carinata seed meals amendment in a greenhouse lettuce production system. Acta Agric. Scand. Sect. B Soil Plant Sci. 2012, 62, 291-299. Available online: https:/ /www.tandfonline.com/doi/abs/10.1080/09064710. 2011.613850 (accessed on 9 November 2018). [CrossRef]

48. Guerrero, M.; Lacasa, C.; Ros, C.; Martínez, V.; Fenoll, J.; Torres, J.; Beltrán, C.; Fernández, P.; Bello, A.; Lacasa, A. Pellets de brasicas como enmiendas para biosolarización de invernaderos de pimiento. XII Congreso Nacional de Ciencias Hortícolas 2009, 1, 1-6. Available online: http:/ / www.sech.info/ACTAS / Acta \%20n\%C2\%BA\%2054.\%20VI\%20Congreso\%20Ib\%C3\%A9rico\% 20de $\% 20$ Ciencias $\% 20$ Hort $\%$ C3\%ADcolas. $\% 20$ XII\%20Congreso $\% 20$ Nacional $\% 20 \mathrm{de} \% 20$ Ciencias $\%$ 20Hort $\%$ C3\%ADcolas /Comunicaciones / Pellets \%20de \%20brasicas \%20como \%20enmiendas \%20para \% 20biosolarizaci\%C3\%B3n\%20de\%20invernaderos\%20de\%20pimiento.pdf (accessed on 9 November 2018).

49. Domene Ruiz, M.A.; Segura Rodriguez, M. Parámetros de calidad externa en la industria agroalimentaria. Publicaciones Cajamar 2014, 1, 1-12. Available online: https:/ / www.cajamar.es/pdf/bd/agroalimentario/ innovacion/investigacion/documentos-y-programas/003-calidad-externa-1401191044.pdf (accessed on 9 November 2018).

50. Domene Ruiz, M.A.; Segura Rodriguez, M. Parámetros de calidad interna en la industria agroalimentaria. Publicaciones Cajamar 2014, 1, 1-18. Available online: https:/ / www.cajamar.es/pdf/bd/agroalimentario/ innovacion/investigacion/documentos-y-programas/005-calidad-interna-1410512030.pdf (accessed on 9 November 2018).

(C) 2019 by the authors. Licensee MDPI, Basel, Switzerland. This article is an open access article distributed under the terms and conditions of the Creative Commons Attribution (CC BY) license (http:/ / creativecommons.org/licenses/by/4.0/). 